\title{
Juvenile survival in a tropical population of roseate terns: interannual variation and effect of tick parasitism
}

\author{
David Monticelli ${ }^{1,2, *}$, Jaime A. Ramos ${ }^{3}$, James E. Hines ${ }^{4}$, James D. Nichols ${ }^{4}$, \\ Jeffrey A. Spendelow ${ }^{4}$
}

\begin{abstract}
${ }^{1}$ Section of Conservation Biology, Royal Belgian Institute of Natural Sciences, 29 Rue Vautier, 1000 Brussels, Belgium
${ }^{2}$ Laboratory of Tropical and Subtropical Forestry, Unit of Forest and Nature Management, Gembloux Agricultural University, 2 Passage des Déportés, 5030 Gembloux, Belgium

${ }^{3}$ Institute of Marine Research (IMAR), Department of Zoology, University of Coimbra, 3004-517 Coimbra, Portugal

${ }^{4}$ Patuxent Wildlife Research Center, US Geological Survey, 12100 Beech Forest Road, Laurel, Maryland 20708, USA
\end{abstract}

\begin{abstract}
Many demographic studies on long-lived seabirds have focused on the estimation of adult survival, but much less is known about survival during the early years of life, especially in tropical species. We report analyses of a capture-recapture dataset of 685 roseate terns ringed as fledglings and adults between 1998 and 2005 on Aride Island, Seychelles, and recaptured/resighted at the same colony site over a 5 yr (2002 to 2006) period. A multistate model was used to estimate survival for different age classes, including juvenile (first-year) birds returning as non-breeding prospectors. The effect of infestation by parasites (ticks) on survival was also examined. Overall, the estimated return of first-year individuals to the natal colony was very variable, ranging from 2 to $22 \%$. Conditioned on survival, the probability of returning from Age 2 yr onwards increased to $70 \%$. Survival rates were best modeled as time-specific, with estimates varying from 0.02 to 1.00 (mean 0.69 ) in firstyear birds with a marked negative effect of tick infestation. In older birds (minimum age of 2 yr), the annual estimates fell between 0.69 and 0.86 (mean 0.77). Using a components of variance approach for estimation of year-to-year variation, we found high temporal variability for first-year individuals (coefficient of variation $[\mathrm{CV}]=65 \%$ ) compared to much less variation in the survival rate of older birds $(C V=9 \%)$. These findings agree with the life-history prediction that demographic rates of juveniles are usually lower and more variable than those of older individuals. Our results are also consistent with the predicted negative effect of tick parasitism on juvenile survival. Compared with data from other roseate tern populations, survival over the first 2 yr (Age 0 to 2 yr) was 18 to $40 \%$ higher in this study, suggesting that a high 'young' survival rate may be an important demographic trait in this tropical population to compensate for the low annual reproductive success. Our data show that estimating survival of young individuals may be crucial to elucidating the demographic tactics of seabirds.
\end{abstract}

KEY WORDS: Ectoparasitism · First-year survival $\cdot$ Multistate capture-recapture models $\cdot$ Temporal variability $\cdot$ Sterna dougallii

\section{INTRODUCTION}

Each animal population living in a particular habitat has a specific pattern of age-related survival that depends upon the adaptation of individuals and the attributes of the environment in which they live
(Weimerskirch 2001). Research into demographic rates of long-lived avian species has suggested that for many species, after attainment of maturity, annual survival is essentially constant regardless of age (Nichols et al. 1997). Moreover, juvenile survival (defined as survival during the first year of life) is often lower than 
that of adults and shows high temporal variation when compared to survival of subsequent age classes (Francis \& Saurola 2004, Harris et al. 2007), a pattern also found in mammals (Gaillard et al. 1998, 2000) and turtles (Chaloupka \& Limpus 2005). In seabirds, fecundity is the demographic trait most affected by variations in environmental conditions, and adult survival is normally high and stable (Nisbet \& Cam 2002) although changes in food availability (Oro \& Furness 2002) and large-scale climatic and weather events (e.g. North Pacific Index [NPI], Jones et al. 2002; hurricanes, Spendelow et al. 2002) are known to induce some variations. Estimates of survival during the prebreeding period are far rarer because many seabird species exhibit a delayed sexual maturity of several years during which they remain away from the breeding grounds and are thus logistically difficult to study (Weimerskirch 2001). As a result, information about the extent to which environmental conditions affect survival during the early years of life from fledging to first breeding or return to the breeding area is still lacking (Weimerskirch 2001). However, despite the important influence of adult survival, a recent study suggested that demographic rates of non-breeding young birds can make a similar relative contribution as those of the adult stage to population growth rate (Ezard et al. 2006). This emphasizes the need to estimate survival and return rates of young individuals of different age classes, ranging from juveniles (1 yr olds, also denoted Age 1) to subadults before recruitment as first-time breeders (i.e. immatures), in understanding the dynamics of a particular population. Such studies perhaps could rely on the recent advances in satellite telemetry (Weimerskirch et al. 2006), but this technology has potential drawbacks, often being applicable to the larger species only and restricted to a small subset of animals within the population studied.

During the last few decades, the development of capture-mark-recapture (CMR) methodologies has provided several ways to infer both survival and recruitment rates of young seabirds that remain unavailable for sampling during their maturation period, but that are later recaptured as breeding adults. This includes mainly multiple-age (Clobert et al. 1994, Williams et al. 2002) and multistate (Pradel \& Lebreton 1999) models dealing with the analysis of capture-recapture histories of animals marked at birth. However, such models are dependent on the proportion of animals exhibiting particular recapture histories, and the estimation of juvenile survival has been limited by a lack of studies in which a substantial number of individuals have been available for sampling as 1 yr olds. So far, the situation encountered is the one where young breeders are sampled for the first time as 2 yr olds or more frequently as 3 yr olds at the colonies (i.e. corresponding to the minimum maturation period), allowing the estimation of young survival over the entire prebreeding period, but not separately for each prebreeding age class (Spendelow et al. 2002, Lebreton et al. 2003).

In larids, although most species start to reproduce for the first time at Age 3 to 4 yr (see Appendix 2 in Schreiber \& Burger 2001), a substantial number of nonbreeding prospectors return to the colonies at Age $2 \mathrm{yr}$ (Gochfeld et al. 1998, Dittmann \& Becker 2003) or in some cases as 1 yr olds (see Shealer \& Burger 1995, Monticelli \& Ramos 2007 in roseate tern Sterna dougallii; Cadiou 1999 in kittiwake Rissa tridactyla). Thus, provided that a sufficient number of 1 yr old birds marked at birth are observable at breeding colonies, a modeling of these recapture histories can be developed in a multistate framework to estimate (1) the survival probabilities from fledgling to Age 1 (= juvenile survival) and subsequent (older) age classes, and (2) the probabilities of returning for the first time to the natal colony at Age 1 (nonbreeding prospector) and at older ages.

The infestation of seabirds by hard ticks (Ixodidae and Amblyommidae) is a common phenomenon reported in many studies (Gauthier-Clerc et al. 2003). In large species such as albatrosses, chick growth and survival may not be negatively affected by tick parasitism (Haemig et al. 1998) but in smaller species, infested chicks may undergo substantial mass losses during the rearing period and high tick densities may cause high levels of chick mortality (Boulinier \& Danchin 1996, Ramos et al. 2001). Surviving chicks usually fledge at a lower mass compared to non-infested chicks, but the implications on postfledging survival are poorly understood. Furthermore, the effects of ticks on their hosts include the transmission of pathogens. For instance, a tick-borne virus has been described previously for Aride Island, Seychelles by sampling breeding roseate terns (Converse et al. 1976), although the effects on seabird survival are unknown.

In this paper, we address the effects of both environmental conditions during chick growth (infestation by ticks) and year-to-year variation (i.e. year as a proxy of oceanographic conditions outside the breeding season) on survival and 'return' probabilities to the natal colony for different age classes. For this analysis, we used a dataset of capture-recapture histories of tropical roseate terns ringed as fledglings during 6 breeding seasons (1998 and 2001 to 2005) on Aride Island, western Indian Ocean, and resighted as either $1 \mathrm{yr}$ old prospectors or at an older age at the same colony site between 2002 and 2006. This type of model also permits the inclusion of adult birds of unknown age (Lebreton et al. 2003), hence individuals ringed as adults between 2002 and 2005 and resighted over the 
2003 to 2006 period were also used in the modeling. According to life-history theory and to specific information available for this population, we made 3 predictions:

(1) We expected that the survival rate of juvenile (1 yr old) roseate terns would be lower than that of subsequent age classes, and that juvenile birds would exhibit higher temporal (interannual) variations in survival than older birds.

(2) Though the return to the natal colony (i.e. philopatry) as young prospectors is a common feature among larids, studies on terns in temperate areas suggest that this prebreeding return occurs mainly from Age 2 onwards rather than for 1 yr old birds (Ratcliffe \& Merne 2002, Dittmann \& Becker 2003). Therefore, we predicted that the probability of returning to Aride as a nonbreeding prospector at Age 1 would be lower than the probability of doing so at an older age.

(3) Finally, we expected that fledglings infested by ticks during the breeding period would exhibit a lower juvenile survival rate compared to non-infested fledglings.

\section{MATERIALS AND METHODS}

Study area, study species and data collection. Aride Island $\left(55^{\circ} \mathrm{E}, 4^{\circ} \mathrm{S}\right)$ holds the largest roseate tern population in the Seychelles. There, the breeding biology of the species was intensively studied between 1998 and 2005 in 2 long-established colonies where 600 to 1200 pairs breed annually (May to July) during the southeast monsoon (Ramos 2001, Ramos et al. 2002). A ringing program of chicks and fledglings was started in 1998, interrupted in 1999 and 2000 due to complete breeding failures (Ramos 2001), and resumed in 2001 to 2005. Each year chicks were ringed annually in 2 study quadrats at hatching with a normal metal ring on the right tarsus, and, for near-fledglings, with a second special 'field-readable' ring on the left tarsus. Hard ticks (Amblyommidae: Amblyomma loculosum) attach to roseate tern chicks from 1 to $3 \mathrm{~d}$ (male tick) to up to 4-14 d (female tick; Ramos et al. 2001), and we knew from our daily visits to the study quadrats whether a chick had a tick at the time of fledgling or had been infested earlier during the season. The effect of engorging female ticks is more detrimental to chick growth than that of males that do not engorge (Ramos et al. 2001), but we did not differentiate between male or female ticks during data analyses since in many cases chicks had ticks of both sexes. A total of 593 fledglings were released during 6 breeding seasons (1998 and 2001 to 2005), while an additional 92 breeding adults were caught by hand at their nests in the study quadrats and ringed (2002 to 2005; Table 1).
Table 1. Sterna dougallii. Recapture histories (year of first resighting) for roseate terns ringed as fledglings (denoted $F_{;}$ 6 cohorts) and as adults ( $A_{i} 4$ cohorts) between 1998 and 2005. No ringing session was conducted in 1999 or 2000 due to complete breeding failures in those years. Resighting of birds did not start until 2002

\begin{tabular}{|c|c|c|c|c|c|c|c|}
\hline \multirow{2}{*}{$\begin{array}{l}\text { Release } \\
\text { year }\end{array}$} & \multirow{2}{*}{$\begin{array}{l}\text { Mark } \\
\text { status }\end{array}$} & \multirow{2}{*}{$\begin{array}{l}\text { Number } \\
\text { released }\end{array}$} & \multicolumn{5}{|c|}{ — Year of first resighting - } \\
\hline & & & 2002 & 2003 & 2004 & 2005 & 2006 \\
\hline $1998^{a}$ & $\mathrm{~F}$ & 97 & 23 & 13 & 4 & 2 & 0 \\
\hline 2001 & F & 117 & 0 & 40 & 13 & 7 & 0 \\
\hline 2002 & $\mathrm{~F}$ & 195 & & 0 & 2 & 1 & 0 \\
\hline & A & 23 & & 15 & 0 & 1 & 0 \\
\hline 2003 & $\mathrm{~F}$ & 78 & & & 1 & 33 & 12 \\
\hline & A & 10 & & & 4 & 1 & 1 \\
\hline 2004 & $\mathrm{~F}$ & 68 & & & & 11 & 32 \\
\hline & A & 34 & & & & 26 & 2 \\
\hline 2005 & $\mathrm{~F}$ & 38 & & & & & 11 \\
\hline & A & 25 & & & & & 17 \\
\hline
\end{tabular}

The left-leg special roseate tern ring has a unique 4 -character alphanumeric combination readable with binoculars or with a spotting scope at up to about $25 \mathrm{~m}$. Resightings were carried out from 2002 to 2006 (June to July) following the field method described in Monticelli \& Ramos (2007). Birds were usually very mobile in and around the colony and were resighted when perching on rocks and logs as naturally available in the breeding area. Although some birds were resighted on many different days, only 1 record per bird per breeding season was used for the modeling. The daily ringreading session was suspended for the season when the curve plotting the number of new birds resighted against the date (daily) reached an asymptote (i.e. several consecutive days with no new individuals). The occurrence of breeding could not be determined for many resightings, except for juvenile birds which are known to be exclusively nonbreeding prospectors on Aride (Monticelli \& Ramos 2007). Available records suggest that first known breeding is at Age 2 but most known breeders were at least 3 yr old (Monticelli \& Ramos 2007).

Capture-recapture modeling. We used multistate capture-recapture models (Arnason 1973, Hestbeck et al. 1991, Lebreton \& Pradel 2002) with unobservable states (Fujiwara \& Caswell 2002, Kendall \& Nichols 2002) corresponding to young birds before their first return visit to the breeding colony. The basic modeling approach was that used by Spendelow et al. (2002) and Lebreton et al. (2003) for the population of roseate terns nesting in Massachusetts, New York and Con- 
necticut (hereafter MA-NY-CT) from Buzzards Bay, MA, west into Long Island Sound. The data correspond to birds ringed as either fledglings or adults and include records of whether each individual was or was not detected in each year following ringing. As with all capture-recapture modeling, the object of the modeling is to identify parameters for the processes that generated the data. We modeled these data using 3 kinds of parameters: survival rates, rates of return to the breeding colony site, and capture-resighting probabilities. Survival rates were permitted to vary by age of the bird, by year, and, for fledglings, by whether or not they were infested by hard ticks. Specifically,

- $S_{t}^{(a)^{\prime}}=$ probability that a bird of Age $a$, infested by tick(s) and alive at the time of ringing in year $t$ is still alive at the approximate time of ringing in year $t+1$. - $S_{t}^{(a)}=$ probability that a bird of Age $a$, not infested by tick(s) and alive at the time of ringing in year $t$ is still alive at the approximate time of ringing in year $t+1$. We developed initial survival models with 3 age classes, juvenile (1 yr old) birds, 2 yr old birds and older birds, but only small numbers of 2 yr olds were available for resighting in some years. These small samples led to identifiability problems that caused us to abandon these models and move to models with survival modeled differently for juveniles, $S_{t}^{(0)}$, and all older birds, $S_{t}^{(1+)}$. Most models retained these 2 age classes, whereas models with a single age class (no difference between survival of juveniles and older birds) simply contain a single survival parameter $\left(S_{t}\right)$ in model notation. The subscript $t$ denotes year-specificity of parameters, whereas a dot indicates a timeconstant parameter. Models that include a tick effect on survival of fledglings include the subscript $T$. Ticks were only present during $3 \mathrm{yr}, 2001$ to 2003. Use of an asterisk between 2 subscripts indicates a relationship that includes interaction terms. For example, $t^{*} T$ indicates that the relationship between ticks and fledgling survival differs among the 3 yr, 2001 to 2003, whereas $t+T$ indicates an additive effect in which the effect of ticks is constant over years. As an example of model notation for the survival component of the models, $\left(S_{t+T}^{(0)}, S^{(1+)}\right)$ denotes a model in which there is an additive relationship between ticks and year for annual survival of fledglings, but that time variation is not important for older birds. We considered one model with a tick effect on time-constant survival of fledglings for 2001 to 2003 and a different constant survival rate for 2004 and $2005\left(S_{(01-03)+T_{(}(04-05)}^{(0)} S^{(1+)}\right.$ ) (see next paragraph for rationale).

Following initial ringing as fledglings, birds were considered in the unobservable state until the first year that they returned to the breeding colony, at which time they entered the observable state. We permitted no transitions from the observable to the unobservable states, so that failure of a bird in the observable state to return to the breeding colony one year was simply a component of resighting probability. Because the only non-zero transitions were from unobservable to observable, we simply denoted these with the parameter $\psi_{t}^{(\mathrm{a})}$, where $t$ denotes year and $a$ indicates age. Our initial modeling indicated that models incorporating variation in transition probability for more than 2 age classes were not supported by the data, so our candidate models included transition parameters for either 2 ages $\left(\psi_{t}^{(0)}, \psi_{t}^{(1+)}\right)$ or 1 age $\left(\psi_{t}^{(\cdot)}\right)$. These transition probabilities are difficult to estimate, and frequently are estimated as constants over years (e.g. Spendelow et al. 2002, Lebreton et al. 2003). However, a priori information that 2004 and possibly 2005 were exceptional return years for young birds (Table 1) led us to consider models with separate parameters for specific sets of years. In one type of model denoted $\left(\psi_{(01-03),(04-05)}^{(0)}\right.$ $\left.\psi^{(1+)}\right), 2001$ to 2003, $\psi_{01-03}^{(0)}$, and 2004 to 2005, $\psi_{04-05}^{(0)}$, were modeled separately. In the other type of model

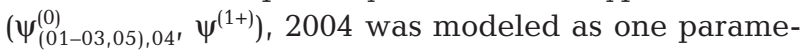
ter $\psi_{04}^{(0)}$ and the remaining years were modeled with another single parameter, $\psi_{01-03,05}^{(0)}$. Return-transition probability for older birds was modeled separately for 2004 to 2005 and 2001 to 2003 in one model, but otherwise always as constant over years. Finally, resighting probability for birds at the breeding colony (observable state) was considered as either time-varying $\left(p_{t}\right)$ or not $(p$.$) .$

As stated above, the initial capture and release of ringed birds was between 2001 and 2005, except for a single cohort of fledglings released in 1998, and recapturing/resighting did not start until 2002 (Table 1). Using different codes for the 2 states, typical recapture histories used in the modeling may be:

- 000FA0, for a bird marked as fledgling at Occasion 4 (2004), resighted as a 1 yr old at Occasion 5 (2005) and not observed at Occasion 6 (2006);

- 0A0A00, for a bird marked as adult at Occasion 2 (2002), not observed at Occasion 3 (2003), resighted at Occasion 4 (2004) and never resighted later.

Unlike with fledglings, adults initially released were of unknown age. The incorporation of such birds in the model is possible because no age-specific modeling of the observable state (A) was attempted (Lebreton et al. 2003). The latter type of recapture history may also apply to fledglings ringed in 1998 that constitute a particular case in the modeling. Since no recapture was conducted before 2002, no age-specific inference was possible for the 1998 fledglings, which entered directly the recapture histories from 2002 onwards in the adult state (i.e. first recapture after initial release in 1998 was considered as an initial adult release). As a result, these birds were first available to be recaptured/ resighted at Occasion 3 (2003). 
Data analysis was conducted using the program MARK (White \& Burnham 1999). To compare temporal variation in survival estimates between juveniles, $S_{t}^{(0)}$, and older birds, $S_{t}^{(1+)}$, we used the Variance Components option. Annual variation in age-specific survival estimates was modeled as a random effect, a procedure that uses the variance-covariance matrix of the estimates to model residual variation in the annual estimates after correcting for sampling error (White \& Burnham 1999, Francis \& Saurola 2004). The removal of variation due to sampling error is an important step in comparing demographic estimates because in many instances, this quantity is a large fraction of the total variation (Gould \& Nichols 1998). We provide coefficients of variation (CV) based on the estimated standard error (SE) of the true temporal variation (i.e. after removal of sampling variability).

Model selection and goodness-of-fit test. We used Akaike's information criterion corrected for small sample size $\left(\mathrm{AIC}_{\mathrm{C}}\right)$ to select the best model among our initial set of candidate models. The model with the lower $\mathrm{AIC}_{\mathrm{C}}$ value was assumed to provide a better explanation of the variation in the data, although models within 2 units of the best AIC-selected model (delta $\mathrm{AIC}_{\mathrm{C}}$ $<2$ ) also can be considered as fitting the data reasonably (Burnham \& Anderson 2002). We implemented a chi-squared goodness-of-fit (GOF) test as proposed in the program U-CARE version 2.2 (Choquet et al. 2005) for the JollyMove (JMV) model, which is a generalization of the Arnason-Schwarz model. Overdispersion in the data may be a cause for lack of fit, and, if warranted, a coefficient referred to as the variance inflation factor ( $\mathrm{c}=\chi^{2} / \mathrm{df}$ ) can be applied to adjust $\mathrm{AIC}_{\mathrm{C}}$ values (Williams et al. 2002).

\section{RESULTS}

\section{Sample size}

Of the 685 roseate terns ringed and released on Aride Island between 1998 and 2005, 272 were re-encountered at least once over the 5 yr spanned by the resighting period (Table 1). Resighting of birds did not start until 2002, hence fledglings ringed in 1998 were first reencountered at Age 4. Noteworthy is the low number of resightings of fledglings ringed in 2002 (Table 1). Overall, the modeling was based on a total of 472 encounters.

\section{Model selection}

The GOF tests performed in U-CARE provided no evidence for lack of fit of the general JMV model $\left(\chi^{2}=\right.$ 8.279 , df $=15, \mathrm{p}=0.912$ ). The set of candidate models (Table 2) based on a priori information (see 'Materials and methods') included various effects (age, year, tick infestation) on survival of fledglings (the probability of surviving the juvenile stage, $S^{(0)}$ ), survival of older birds (the annual survival probability following Age 1, $\left.S^{(1+)}\right)$, transition probabilities for juveniles and older birds (conditional on survival, the probability of returning for the first time to the natal site as a juvenile bird, $\psi^{(0)}$, or after Age $\left.1, \psi^{(1+)}\right)$, and probability of recapture. The best supported model based on $\mathrm{AIC}_{\mathrm{c}}$ selection was as follows (Table 2): annual survival of juveniles was modeled as a function of both time and ticks, with an interaction term for these 2 sources of variation; annual survival for older birds was also modeled as a function of time; return transition probability was modeled as time-varying (years 2001 to 2003, 2004 to 2005) for juveniles and as a constant over time for older birds; and resighting probability was modeled as varying

Table 2. Model selection results based on Akaike's information criterion corrected for small sample sizes $\left(\mathrm{AIC}_{\mathrm{C}}\right)$. The set of models includes various effects (age, year $[t]$, tick infestation [T]) on survival of fledglings $\left(S^{(0)}\right)$, survival of older birds $\left(S^{(1+)}\right)$, return transition probability for fledglings $\left(\psi^{(0)}\right)$ and older birds $\left(\psi^{(1+)}\right)$, and probability of recapture $(p)$

\begin{tabular}{|c|c|c|c|}
\hline Model & $\begin{array}{l}\text { Delta } \\
\text { AIC }_{c}\end{array}$ & $\begin{array}{c}\text { No. of } \\
\text { parameters }\end{array}$ & Deviance \\
\hline$\left(S_{t}^{(0)}, S_{t}^{(1+)}, \psi_{(01-03),(04-05)}^{(0)} \psi^{(1+)}, p_{t}\right)$ & 0.00 & 19 & 1251.67 \\
\hline$\left(S_{t \cdot T^{\prime}}^{(0)} S_{\cdot}^{(1+)}, \psi_{(01-03),(04-05)}^{(0)} \psi_{\cdot}^{(1+)}, p_{t}\right)$ & 0.20 & 16 & 1258.12 \\
\hline$\left(S_{t+T}^{(0)}, S_{\cdot}^{(1+)}, \psi_{(01-03),(04-05)}^{(0)} \psi_{\cdot}^{(1+)}, p_{t}\right)$ & 0.47 & 17 & 1256.31 \\
\hline$\left(S_{t+T}^{(0)}, S^{(1+)}, \psi_{(01-03),(04-05),}^{(0)} \psi_{.}^{(1+)}, p_{t}\right)$ & 1.15 & 14 & 1263.21 \\
\hline$\left(S_{t}^{(0)} T^{\prime}, S_{t}^{(1+)}, \psi_{(01-03),(04-05)^{\prime}}^{(0)} \psi_{(01-03),(04-05)^{\prime}}^{(1+)} p_{t}\right)$ & 1.70 & 20 & 1251.28 \\
\hline$\left(S_{t}^{(0)}, S_{t}^{(1+)}, \psi_{(01-03),(04-05)^{\prime}}^{(0)} \psi^{(1+)}, p_{t}\right)$ & 6.29 & 16 & 1264.21 \\
\hline$\left(S_{t}^{(0)}, S_{\cdot}^{(1+)}, \psi_{(01-03),(04-05)^{\prime}}^{(0)} \psi_{\cdot}^{(1+)}, p_{t}\right)$ & 7.61 & 14 & 1269.67 \\
\hline$\left(S_{t+a^{*} T}, \psi_{(01-03),(04-05)}^{(0)} \psi^{(1+)}, p_{t}\right)$ & 51.98 & 16 & 1309.90 \\
\hline$\left(S_{t+a^{\prime}} \psi_{(01-03),(04-05)^{\prime}}^{(0)} \psi_{.}^{(1+)}, p_{t}\right)$ & 64.35 & 13 & 1328.47 \\
\hline$\left(S_{(01-03)+T,(04-05)}^{(0)} S^{(1+)}, \psi_{(01-03),(04-05),}^{(0)} \psi_{{ }^{(1+)}}^{(1+)} p_{t}\right)$ & 139.76 & 11 & 1407.99 \\
\hline$\left(S_{(01-03),(04-05)^{\prime}}^{(0)} S^{(1+)}, \psi_{(01-03),(04-05)^{\prime}}^{(0)} \psi^{(1+)}, p_{t}\right)$ & 161.59 & 11 & 1429.82 \\
\hline$\left(S_{(01-03),(04-05)^{\prime}}^{(0)} S_{.}^{(1+)}, \psi_{(01-03),(04-05)^{\prime}}^{(0)} \psi_{.}^{(1+)}, p.\right)$ & 185.70 & 7 & 1462.10 \\
\hline$\left(S_{(01-03,05), 04}^{(0)}, S_{.}^{(1+)}, \psi_{(01-03,05), 04}^{(0)} \psi_{.}^{(1+)}, p.\right)$ & 233.21 & 7 & 1509.61 \\
\hline$\left(S_{(01-03,05), 04}^{(0)}, S_{.}^{(1+)}, \psi_{.}^{(0)}, \psi_{.}^{(1+)}, p.\right)$ & 235.38 & 6 & 1513.81 \\
\hline$\left(S_{01,(02-05)}^{(0)} S^{(1+)}, \psi_{(01-03,05), 04}^{(0)} \psi_{.}^{(1+)}, p.\right)$ & 255.10 & 7 & 1531.50 \\
\hline$\left(S_{01,(02-05)}^{(0)} S_{.}^{(1+)}, \psi_{.}^{(0)}, \psi_{.}^{(1+)}, p_{.}\right)$ & 262.74 & 6 & 1541.17 \\
\hline$\left(S_{.}^{(0)}, S_{\cdot}^{(1+)}, \psi\left({ }^{(0)}, \psi^{(1+)}, p.\right)\right.$ & 277.38 & 5 & 1577.84 \\
\hline$\left(S_{.}^{(0)}, S_{\cdot}^{(1+)}, \psi_{\cdot}^{(0)}, \psi_{.}^{(1)}, \psi_{\cdot}^{(2+)}, p.\right)$ & 279.19 & 6 & 1577.63 \\
\hline$\left(S_{.}, \psi_{,} p_{.}\right)$ & 375.59 & 3 & 1660.09 \\
\hline$\left(S_{.}^{(0)}, S_{\cdot}^{(1+)}, \psi_{.}, p_{.}\right)$ & 377.51 & 4 & 1660.00 \\
\hline
\end{tabular}


over time. Several competing models were developed a posteriori by simplifying the best AIC-supported model, but none of them produced a smaller $\mathrm{AIC}_{\mathrm{C}}$ value (Table 2). These additional models included models with constant survival after Age 1 and/or constant effect of ticks over years.

\section{Juvenile (1 yr old) survival estimate}

The probability of surviving the first year of life was very high ( $>0.87$; Table 3 ) for these roseate terns, except over the 2002 to 2003 time period when survival was close to zero (0.02). Thus overall, the mean juvenile survival estimate was decreased to 0.69. As suspected, in years when ticks were abundant in the colony, the juvenile survival of infested fledglings was lowered, being about $25 \%$ that of non-infested birds (Table 3). This was less evident for the 2002 fledglings simply because very few birds apparently survived from this cohort (3 birds recaptured out of 195; Table 1), making it difficult to model survival estimates of infested versus non-infested birds.

\section{Survival estimate after Age 1}

The survival estimates of roseate terns after Age 1 ( 2 yr olds and older birds) were less variable than those of juvenile birds (Table 3), ranging from 0.69 to 0.86 (mean $=0.77$ ). After removing the effects of sampling error, the year-to-year (temporal) variation in annual survival rates was much higher in juveniles compared to older individuals (CV: 0.651 vs. 0.086 , respectively; Table 3). A negative temporal variance was estimated for 1 yr old birds infested with ticks (-0.00123), suggesting that temporal variation was close to zero, or

Table 3. Sterna dougallii. Survival probabilities of juveniles (1 $\mathrm{yr}$ old) ringed as fledglings in relation to infestation with ticks and survival probabilities of birds older than Age 1 ( 2 yr olds and older birds). Estimates $( \pm$ SE) are from the model with the lowest $\mathrm{AIC}_{\mathrm{c}}$ value (= final model; Table 2)

\begin{tabular}{|c|c|c|c|}
\hline \multirow{2}{*}{ Time period } & \multicolumn{2}{|c|}{1 yr old } & \multirow{2}{*}{$\begin{array}{l}\text { Older than } \\
\text { Age } 1\end{array}$} \\
\hline & Tick absent & Tick present & \\
\hline 2001 to 2002 & $0.885 \pm 0.123$ & $0.204 \pm 0.192$ & \\
\hline 2002 to 2003 & $0.019 \pm 0.014$ & $0.035 \pm 0.035$ & $0.693 \pm 0.072$ \\
\hline 2003 to 2004 & $0.873 \pm 0.097$ & $0.197 \pm 0.182$ & $0.756 \pm 0.050$ \\
\hline 2004 to 2005 & $1.000^{\mathrm{a}}$ & No tick ${ }^{b}$ & $0.862 \pm 0.039$ \\
\hline Mean & 0.694 & 0.145 & 0.770 \\
\hline $\mathrm{CV}$ & 0.651 & & 0.086 \\
\hline
\end{tabular}

that variability due to sampling error was large compared to the true temporal variability (Gould \& Nichols 1998).

\section{First return to the colony and recapture probabilities}

Transition probabilities and recapture estimates are presented in Tables $4 \& 5$, respectively. The return rate as juvenile (1 yr old) prospectors of fledglings released from 2001 to 2003 was estimated at $2 \%$, increasing to $22 \%$ for those released in 2004 and 2005 (Table 4). Probability of initial return of birds older than Age 1 (i.e. as 2 yr olds or at an older age) was much higher, estimated at $70 \%$. The absence of recaptures of $1 \mathrm{yr}$ old birds in 2002 led to a zero recapture estimate for that year (Table 5), while recapture estimates were high in other years, presumably reflecting the good proportion of birds (fledglings plus adults) resighted the year directly following their initial release (Table 1).

\section{DISCUSSION}

\section{Statistical modeling}

The significant interannual difference in recapture/ resighting probability (Table 5) points out that any inference based on ad hoc return rates (proportion of birds recaptured relative to the annual ringing effort) would have produced biased survival estimates. This

Table 4. Sterna dougallii. Conditional (on survival) probabilities of returning for the first time to the natal colony as a juvenile (1 yr old prospector) or after Age 1 for birds ringed as fledglings (estimate $\pm \mathrm{SE}$, final model)

\begin{tabular}{|ccc|}
\hline Time period & 1 yr old & Older than Age 1 \\
\hline 2001 to 2002 & $0.020 \pm 0.020$ & \\
2002 to 2003 & $0.020 \pm 0.020$ & $0.700 \pm 0.060$ \\
2003 to 2004 & $0.020 \pm 0.020$ & $0.700 \pm 0.060$ \\
2004 to 2005 & $0.223 \pm 0.043$ & $0.700 \pm 0.060$ \\
2005 to 2006 & $0.223 \pm 0.043$ & $0.700 \pm 0.060$ \\
\hline
\end{tabular}

Table 5. Sterna dougallii. Recapture/resighting probabilities (estimate $\pm \mathrm{SE}$, final model)

\begin{tabular}{|cc|}
\hline Year of recapture & Estimate \\
\hline 2002 & $0.000 \pm 0.000$ \\
2003 & $0.904 \pm 0.067$ \\
2004 & $0.680 \pm 0.054$ \\
2005 & $0.898 \pm 0.032$ \\
\hline
\end{tabular}


motivates the use of a formal modeling of the capture-resight data to yield more rigorous estimates. Here, we relied on a multistate approach corresponding to the case where individuals marked at birth may be in 1 of 2 phenotypic states in subsequent years (multistate model with 2 states only; Pradel \& Lebreton 1999). This choice was related to the biological assumption that survival and return probabilities of juvenile birds may differ from those of older birds and was especially appropriate because of our interest in estimating age-specific return rates.

Based on a priori information on this population, a set of candidate models with 2 age classes, juveniles and older birds, was established, of which a final model emerged with 3 main results: (1) survival probability varied importantly among age classes and time periods, (2) however, after removing the variation due to sampling error, survival was much less variable in older birds compared to juveniles and (3) a significant negative effect of tick parasitism (Amblyommidae: Amblyomma loculosum) on juvenile survival lowered the estimates by a factor of 4 . These results were generally consistent with the a priori predictions and biological knowledge of this population and are discussed below.

\section{Survival estimates and temporal variation}

Survival estimates of seabird species during the first years of life (juvenile, immature stage) are rare in the avian literature (but see Harris et al. 2007). In the present study, the estimation of juvenile survival using CMR modeling was made possible due to a substantial number of young roseate terns observable from Age 1 onwards, a situation rather unusual in temperate areas because most birds remain away from the natal site until Age 3 (Gochfeld et al. 1998). Substantial numbers of juveniles returning to the natal colony are also frequently observed in other tropical roseate tern populations (Shealer \& Burger 1995), a pattern also found in common terns Sterna hirundo breeding in the tropics (LeCroy 1976).

The modeling of recapture histories found timespecific survival rate estimates ranging from 0.02 to 1.00 (mean 0.69) during the juvenile stage, increasing to 0.69 to 0.86 (mean 0.77 ) in 2 yr old and older individuals (second age class). Thus, with the exception of a marked effect of ticks and severe winter conditions in 2002 to 2003 (see next paragraph), juvenile survival rates were usually high, and over the 2004 to 2005 time period, virtually all fledglings survived the first year (boundary estimate). Survival estimates for the fledglings released in 2005 and resighted in 2006 were not available (i.e. survival and recapture probabilities are confounded in the model), but the high proportion of returning birds (11 out of 38; Table 1 ) indicates that survival was probably also high for that cohort. As expected in long-lived species, survival was on average higher in the second year of life and subsequent years (Francis \& Saurola 2004). Moreover, after accounting for sampling variation, we found a much higher temporal variability in survival of juveniles than in that of older individuals (CV: 0.65 vs. 0.09, respectively), consistent with the general pattern of lifehistory traits in long-lived animals (Gaillard et al. 2000, Schaub et al. 2005). This pattern suggests that juveniles are affected more strongly by environmental variation during postfledging, migration and overwintering (Spendelow et al. 2002, Schaub et al. 2005, Ezard et al. 2006). This may be especially the case in tern species, as recently fledged juveniles are still largely dependent on their parents for food during several months (post-breeding care) up to the winter quarters.

Without direct measure of food availability during the interbreeding season (i.e. August to April), year-toyear variations provide an indirect way to assess the effects of environmental fluctuations on demographic parameters. On Aride, we previously showed that roseate tern reproductive parameters are influenced by interannual variations in food supply conditions around the colonies, which in turn are driven by largeand local-scale phenomena (El Niño and local oceanic productivity, respectively; Monticelli et al. 2007). There is, however, comparatively little information on local conditions during migration and at overwintering quarters. Warman (1979) reported fledged juveniles loafing in flocks on the Aride shore before dispersalmigration, suggesting that post-fledging fitness is likely to be affected by food supply conditions around the colonies at the end of the breeding season. While our own data revealed that birds do not remain around the island more than a few weeks post-breeding (D. Monticelli \& J. A. Ramos unpubl. data), we suspected that an acute food shortage period that occurred in 2002 could be connected, at least in part, to the very high mortality rate of juveniles in 2002 to 2003 (Table 3). In fact, detailed observations suggested that oceanic primary productivity recorded within a $50 \mathrm{~km}$ radius around Aride (denoted by estimates of chlorophyll concentration [CC]) was very low in July 2002 (see Fig. 4 in Monticelli et al. 2007), about 1 wk after most roseate tern chicks had started to fledge and to form clubs on the rocky shore of the island. At the same time, a massive chick starvation event was reported on Aride in other seabird species (e.g. lesser noddy Anous tenuirostris; Ramos \& Monticelli 2007). However, a repeat of our modeling including CC data as a cohort-level covariate of juvenile survival did not produce any significant effect on this demographic 
trait, suggesting that environmental factors affecting roseate tern survival are more likely to be those acting when fledglings are away from Aride Island. Further evidence of severe environmental conditions encountered by this species during the 2002 to 2003 interbreeding season arose from the low annual survival probabilities also obtained in older birds (second age class; Table 3). This suggests that all individuals were probably subject to the same abnormal migrating and overwintering conditions, yet juvenile birds were affected more strongly. A similar situation has been recently described for juvenile and adult common guillemots Uria aalge in the North Sea (Harris et al. 2007), while in the North American roseate tern population, the effect of a hurricane in August 1991 was found to be much greater on survival of the young than of adults (Spendelow et al. 2002, Lebreton et al. 2003).

\section{Effects of tick parasitism on survival}

Avian fitness is affected by multiple sources of stochastic variation, including the infestation by parasites at colonies (Boulinier \& Danchin 1996). The life cycle of the tick Amblyomma loculosum coincides with the breeding season of seabirds on Aride (May to September), including the roseate tern, but the extent to which fledglings are infested is variable from year to year. Ramos et al. (2001) suggested that the infestation level of nestlings is cyclic, following cycles of successful and unsuccessful breeding seasons. For instance, in years of poor food supply conditions around the island, roseate terns can be subject to a complete breeding failure (massive hatching failure and chick mortality). Consequently, ticks cannot successfully complete their life cycle due to a lack of hosts (i.e. chicks), thereby lowering the level of chick infestation in subsequent years. Conversely, years of high roseate tern productivity are likely to be also favorable for ticks and result in enhanced levels of infestation in the following season. We also showed (Monticelli et al. 2008a) that characteristics of the roseate tern nesting habitat are a proximate factor influencing the infestation levels of nestlings by ticks. On Aride, roseate terns nest on the forest floor under a tree (Pisonia grandis) canopy, where the more enclosed and vegetated areas present higher tick densities, presumably due to damper conditions that favor tick survival. A large clearing created within the usual breeding area in 2004 decreased the level of chick infestation by ticks (Monticelli et al. 2008a), hence none of the fledglings involved in the present study were infested in that year (Table 3). During the other years, $13 \%$ of the 525 roseate tern fledglings included in the analyses were infested during chick growth or at the time of ringing.
Gauthier-Clerc et al. (2003) studied the infestation of adult king penguins Aptenodytes patagonicus by the hard tick Ixodes uriae (Ixodidae) but found no effect on their survival rates during 3 consecutive years. Much less is known, however, about the effects of ticks during the juvenile stage when birds are much more sensitive to various forms of environmental stochasticity. Previous work suggested that tick parasitism during the breeding season may increase postfledging mortality because a fledgling that had been infested by a female tick during the rearing period was recovered dead $76 \mathrm{~km}$ away from Aride (Bird Island; Ramos et al. 2001). The low survival estimates found in the present study (Table 3 ) are thus consistent with this prediction. Infested individuals may be especially affected during the postfledging period if food conditions are poor (Ramos et al. 2001). Although these results clearly indicate that survival is very low in infested young birds, the large standard deviation and difficulty in estimating temporal variance make it difficult to quantify possible variations in tick effects between years, so more data are needed to fully assess this point.

\section{Return-recruitment estimates}

The transition probabilities in the model were biologically interesting because they permitted agespecific estimation of the propensity to return to the natal site. Juveniles seen at the colony were nonbreeding individuals prospecting for the first time (Monticelli \& Ramos 2007), while in their second and subsequent years, birds either returned as prospectors or were recruited in the population as breeders. The distinction between the latter 2 states during modeling is conceptually possible in multistate models (Lebreton et al. 2003), but our resighting method did not differentiate between breeders and prospectors. This behavioral difference may have induced some heterogeneity in recapture probabilities of young birds and violates an assumption required by mark-recapture models. The consequences of such an assumption violation are, however, not well known in multistate models, although transition probability may be the less robust estimator compared to survival probability (Williams et al. 2002). As for survival rates, the return rate of juveniles varied importantly between years, ranging from 2 to $22 \%$, but interpretation of these absolute values should be made with caution. Such interannual fluctuations may perhaps be linked to the prevalent food conditions during the previous winter and at the breeding colonies. The high return rate estimate of juveniles in 2004 to 2005 coincided with the 2 yr of highest marine productivity recorded in the vicinity of Aride Island over the 1997 to 2005 period (Monticelli \& 
Table 6. Sterna dougallii. Summary of survival estimates obtained in most recent CMR studies conducted in temperate latitudes (North Atlantic) and in the tropics (tropical Atlantic and Indian Oceans)

\begin{tabular}{|c|c|c|c|c|}
\hline \multirow{2}{*}{$\begin{array}{l}\text { Location of breeding } \\
\text { colonies }\end{array}$} & \multirow[t]{2}{*}{ Study period } & \multicolumn{2}{|c|}{ - Survival estimate } & \multirow[t]{2}{*}{ Study } \\
\hline & & Age 0 to $2 \mathrm{yr}$ & Adult (Age 3+ yr) & \\
\hline \multirow[t]{2}{*}{ North America } & 1988 to 1992 & & 0.74 to 0.84 & Spendelow et al. (1995) \\
\hline & 1988 to 1998 & 0.37 & 0.81 to 0.84 & Lebreton et al. (2003) \\
\hline Europe & 1995 to 2007 & & 0.75 to 0.84 & Ratcliffe et al. (2008) \\
\hline Caribbean & 1991 to 1994 & 0.44 & 0.71 to 0.80 & Shealer et al. (2005) \\
\hline Seychelles & 1998 to 2007 & $0.52^{\mathrm{a}}$ & 0.73 to 0.86 & Monticelli et al. (2008b); present study \\
\hline
\end{tabular}

Ramos 2007, Monticelli et al. 2007). The return/recruit rate into the Aride colony increased to $70 \%$ in subsequent years, with less evidence of interannual variations (Table 4). This is consistent with the widely reported propensity in larids, and terns in particular, to return to the colonies more frequently from Age 2 onwards (e.g. Dittmann \& Becker 2003).

\section{Comparison with other roseate tern populations}

Most recent CMR studies on roseate terns breeding in temperate latitudes (North Atlantic) and in the tropics (tropical Atlantic) have estimated survival over the whole prebreeding period (minimum 2 yr) and compared it with that of breeding adults (3 yr and more; Table 6). Young survival over the first $2 \mathrm{yr}$ can be estimated in the present study at $0.52(0.69 \times 0.77)$, which is $18 \%$ higher than in the tropical Atlantic population (Caribbean) and up to $40 \%$ higher than in the temperate North American (MA-NY-CT) population (Table 6). In contrast, survival estimates for breeding adults (3 yr olds and more) on Aride have been recently found to fall within the range of those of other populations (Table 6).

Comparative studies of demographic traits among seabird taxa have placed species on a slow-fast gradient expressing the trade-offs between survival and fecundity (see Weimerskirch 2001). Comparing demographic rates between populations living in contrasted environments provides a good example to test the hypothesis related to the low productivity of tropical waters (Weimerskirch 2001). Life-history theory predicts that the low productivities of tropical colonies should be compensated by high survival rates. Conversely, in populations living in more productive waters (e.g. temperate areas), fecundity is higher (higher average clutch size, higher breeding success) but is balanced by lower survival rates. In the roseate tern, the average clutch size is larger in temperate populations (North America: 1.7 to 1.9 eggs clutch $^{-1}$; Gochfeld et al. 1998) compared to tropical ones (Aride:
1.2 eggs clutch $^{-1}$, Ramos et al. 2002; Caribbean: 1.5 eggs clutch $^{-1}$, Gochfeld et al. 1998). Frequent breeding failures also are reported in the tropics, resulting in a much lower average productivity (Aride: 0.5 fledglings pair ${ }^{-1}$; Ramos et al. 2002, Monticelli et al. 2007) compared to temperate populations (North America: 1.0 to 1.2 fledglings pair ${ }^{-1}$; Burger et al. 1996, Nisbet \& Spendelow 1999). Therefore, a trade-off for the lower fecundity of roseate terns breeding in the tropics may lie in higher survival rates. Whereas Monticelli et al. (2008b) did not find any evidence of enhanced adult survival, the present study revealed much higher survival rates in young tropical roseate terns (Age 0 to 2 yr) compared to their temperate counterparts. The large temporal variation observed in juveniles $(\mathrm{CV} \approx 65 \%)$ also suggests that young survival is likely to have the largest influence on temporal variation in population growth rate compared to the adult stage (e.g. Gaillard et al. 2000, Ezard et al. 2006). Thus, we suspect that the high survival rate exhibited by young tropical roseate terns on Aride could be useful to balance the low annual reproductive success. Further studies using population matrix modeling could be important in testing this hypothesis.

Acknowledgements. We are indebted to J. Cadbury and the Island Conservation Society for permission to work on Aride. This study was partially funded by J. Cadbury (travel assistance), the King Leopold III Fund for Nature Exploration and Conservation, and a doctoral grant to D.M. (Contract WI-36D03). We are grateful to I. Nisbet for valuable comments on the manuscript. Bird ringing was undertaken under license of the Portuguese Bird Ringing Centre with the special roseate tern 'field-readable' rings provided by N. Ratcliffe at the Royal Society for the Protection of Birds, UK. The work conforms to the legal requirements of the Republic of Seychelles where it was conducted.

\section{LITERATURE CITED}

Arnason AN (1973) The estimation of population size, migration rates, and survival in a stratified population. Res Popul Ecol (Kyoto) 15:1-8

Boulinier T, Danchin E (1996) Population trends in kittiwake Rissa tridactyla colonies in relation to tick infestation. Ibis 138:326-334 
Burger J, Nisbet ICT, Safina C, Gochfeld M (1996) Temporal patterns in reproductive success in the endangered roseate tern (Sterna dougallii) nesting on Long Island, New York, and Bird Island, Massachusetts. Auk 113:131-142

Burnham KP, Anderson DR (2002) Model selection and multimodel inference: a practical information-theoretic approach, 2nd edn. Springer, New York

Cadiou B (1999) Attendance of breeders and prospectors reflects the quality of colonies in the Kittiwake Rissa tridactyla. Ibis 141:321-326

Chaloupka M, Limpus C (2005) Estimates of sex- and ageclass-specific survival probabilities for a southern Great Barrier Reef green sea turtle population. Mar Biol 146: 1251-1261

Choquet R, Reboulet AM, Lebreton JD, Gimenez O, Pradel R (2005) U-CARE 2.2 user's manual. CEFE, Montpellier

Clobert J, Lebreton JD, Allaine D, Gaillard JM (1994) The estimation of age-specific breeding probabilities from recaptures or resightings of marked animals. II. Longitudinal models. Biometrics 50:375-387

> Converse JD, Hoogstraal H, Moussa MI, Kaiser MN, Casals J, Feare CJ (1976) Aride virus, a new ungrouped arbovirus infecting Amblyomma loculosum ticks from roseate terns in the Seychelles. Arch Virol 50:237-240

> Dittmann T, Becker PH (2003) Sex, age, experience and condition as factors affecting arrival date in prospecting common terns, Sterna hirundo. Anim Behav 65:981-986

Ezard THG, Becker PH, Coulson T (2006) The contributions of age and sex to variation in common tern population growth rate. J Anim Ecol 75:1379-1386

Francis CM, Saurola P (2004) Estimating components of variance in demographic parameters of tawny owls, Strix aluco. Anim Biodivers Conserv 27:489-502

Fujiwara MF, Caswell H (2002) A general approach to temporary emigration in mark-recapture analysis. Ecology 83: 3266-3275

- Gaillard JM, Festa-Bianchet M, Yoccoz NG (1998) Population dynamics of large herbivores: variable recruitment with constant adult survival. Trends Ecol Evol 13:58-63

Gaillard JM, Festa-Bianchet M, Yoccoz NG, Loison A, Toigo C (2000) Temporal variation in fitness components and population dynamics of large herbivores. Annu Rev Ecol Syst 31:367-393

Gauthier-Clerc M, Mangin S, Le Bohec C, Gendner JP, Le Maho Y (2003) Comparison of behaviour, body mass, haematocrit level, site fidelity and survival between infested and non-infested king penguin Aptenodytes patagonicus by ticks Ixodes uriae. Polar Biol 26:379-382

Gochfeld M, Burger J, Nisbet ICT (1998) Roseate tern (Sterna dougallii). In: Poole A, Gill F (eds) The birds of North America, No. 370. The Birds of North America, Philadelphia, PA

Gould WR, Nichols JD (1998) Estimation of temporal variability of survival in animal populations. Ecology 79:2531-2538

- Haemig PD, Bergström S, Olsen B (1998) Survival and mortality of grey-headed albatross chicks in relation to infestation by the tick Ixodes uriae. Colon Waterbirds 21:452-453

Harris MP, Frederiksen M, Wanless S (2007) Within- and between-year variation in the juvenile survival of common guillemots Uria aalge. Ibis 149:472-481

> Hestbeck JB, Nichols JD, Malecki RA (1991) Estimates of movement and site fidelity using mark-resight data of wintering Canada geese. Ecology 72:523-533

$>$ Jones IL, Hunter FM, Robertson GJ (2002) Annual adult survival of least auklets (Aves, Alcidae) varies with largescale climatic conditions of the North Pacific Ocean. Oecologia 133:38-44
Kendall WL, Nichols JD (2002) Estimating state-transition probabilities for unobservable states using capturerecapture/resighting data. Ecology 83:3276-3284

> Lebreton JD, Pradel R (2002) Multistate recapture models: modelling incomplete individual histories. J Appl Stat 29: 353-369

> Lebreton JD, Hines JE, Pradel R, Nichols JD, Spendelow JA (2003) Estimation by capture-recapture of recruitment and dispersal over several sites. Oikos 101:253-264

LeCroy M (1976) Bird observations in Los Roques, Venezuela. Am Mus Novit 2599:1-30

Monticelli D, Ramos JA (2007) Plumage characteristics and return rate of one-year-old tropical roseate terns. Waterbirds 30:58-63

Monticelli D, Ramos JA, Quartly GD (2007) Effects of annual changes in primary productivity and ocean indices on breeding performance of tropical roseate terns in the western Indian Ocean. Mar Ecol Prog Ser 351:273-286

Monticelli D, Ramos JA, Doucet JL (2008a) Influence of woodland cover on habitat selection and reproductive parameters of tropical roseate terns: implications for colony management. Endang Species Res 4:257-266

Monticelli D, Ramos JA, Guerreiro-Milheiras SA, Doucet JL (2008b) Adult survival of tropical roseate terns on Aride Island, Seychelles, western Indian Ocean. Waterbirds (in press)

Nichols JD, Hines JE, Blums P (1997) Tests for senescent decline in annual survival probabilities of common pochards, Aythya ferina. Ecology 78:1009-1018

Nisbet ICT, Cam E (2002) Test for age-specificity in survival of the common tern. J Appl Stat 29:65-83

Nisbet ICT, Spendelow JA (1999) Contribution of research to management and recovery of the roseate tern: review of a twelve-year project. Waterbirds 22:239-252

Oro D, Furness RW (2002) Influences of food availability and predation on survival of kittiwakes. Ecology 83:2516-2528

Pradel R, Lebreton JD (1999) Comparison of different approaches to the study of local recruitment of breeders. Bird Study 46(Suppl):S74-S81

Ramos JA (2001) Seasonal variation in reproductive measures of tropical roseate terns Sterna dougallii: previously undescribed breeding patterns in a seabird. Ibis 143:83-91

> Ramos JA, Monticelli D (2007) Long-term studies on productivity of roseate terns and lesser noddies on Aride Island, Seychelles. Ostrich 78:443-447

Ramos JA, Bowler J, Davis L, Venis S, Quinn J, Middleton C (2001) Activity patterns and effect of ticks on growth and survival of tropical roseate tern nestlings. Auk 118:709-716

Ramos JA, Maul AM, Ayrton V, Bullock I and others (2002) Influence of local and large-scale weather events and timing of breeding on tropical roseate tern reproductive parameters. Mar Ecol Prog Ser 243:271-279

Ratcliffe N, Merne O (2002) Roseate tern (Sterna dougallii). In: Wernham CV, Toms MP, Marchant JH, Clark JA, Siriwardena G, Baillie SR (eds) The migration atlas: movements of birds of Britain and Ireland. Poyser, London, p 385-387

Ratcliffe N, Newton S, Morrison P, Merne O, Cadwallender T, Frederiksen M (2008) Adult survival and breeding dispersal of roseate terns within the northwest European metapopulation. Waterbirds (in press)

Schaub M, Kania W, Koppen U (2005) Variation of primary production during winter induces synchrony in survival rates in migratory white storks Ciconia ciconia. J Anim Ecol 74:656-666

Schreiber EA, Burger J (2001) Biology of marine birds. CRC Press, Boca Raton, FL 
Shealer DA, Burger J (1995) Comparative foraging success between adults and one-year-old roseate and sandwich terns. Waterbirds 18:93-99

Shealer DA, Saliva JE, Pierce J (2005) Annual survival and movement patterns of roseate terns breeding in Puerto Rico and the U.S. Virgin Islands. Waterbirds 28:79-86

Spendelow JA, Nichols JD, Nisbet ICT, Hays H and others (1995) Estimating annual survival and movement rates of adults within a metapopulation of roseate terns. Ecology 76:2415-2428

Spendelow JA, Nichols JD, Hines JE, Lebreton JD, Pradel R (2002) Modeling postfledging survival and age-specific breeding probabilities in species with delayed maturity: a case study of roseate terns at Falkner Island, Connecticut. J Appl Stat 29:385-405

Warman SR (1979) The roseate tern Sterna dougallii aridensis

Editorial responsibility: Rory Wilson,

Swansea, UK on Aride Island, Seychelles. Bull Br Ornithol Club 99: 124-128

Weimerskirch H (2001) Seabird demography and its relationship with the marine environment. In: Schreiber EA, Burger J (eds) Biology of marine birds. CRC Press, Boca Raton, FL, p 115-136

Weimerskirch H, Akesson S, Pinaud D (2006) Postnatal dispersal of wandering albatrosses Diomedea exulans: implications for the conservation of the species. J Avian Biol 37: $23-28$

White GC, Burnham KP (1999) Program MARK: survival estimation from populations of marked animals. Bird Study 46(Suppl):S120-S139

Williams BK, Nichols JD, Conroy MJ (2002) Analysis and management of animal populations. Academic Press, San Diego, CA

Submitted: December 26, 2007; Accepted: April 4, 2008

Proofs received from author(s): July 30, 2008 